DAT: 3ASES FOR RAPID RESPO:SE TO POWER REACTCR ?POELEYS *

Bett: F. :Las::?itz

Engineering Phisies Laforation Cencess (EPIC)

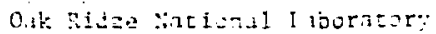

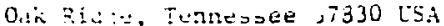

\title{
$\cos \cdot \cos 095-1$
}

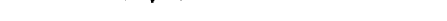

iNTERDCTE::

On March 24, 1979 news was flashed arcund the sorld of an ongoing reacter accident in thit 2 of the

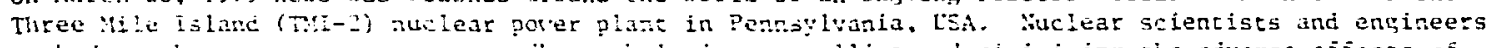
rushed to the scene or were un stundb: to ietp in concroiltng and jirimizing the adverse eriects of the accidert. Around the norld $R \& D$ fersinel of the nuclear power industr $\because$ listened to reports of the accident, did ealculaticas ant ran computer simulations in an ef zozt to understanu and possibly advise tie lis. cechnologists. Satiation protecticn and seíety were of concera to all.

\begin{abstract}
Almost two years has passed since the Nil-: aceident first captured rews heailines rith threat of an impending molear disascer. The iacident has been thoreughly stutied (Andrevs II, 1980) and

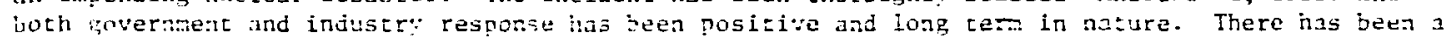
reurniniation of priorities ritian governent researia and regulasuz $\because$ bodies and t:o major institu-

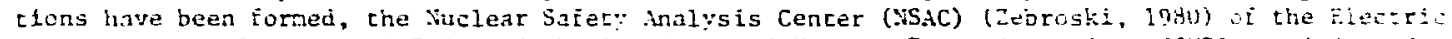

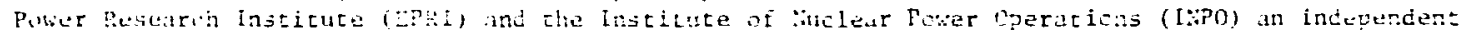

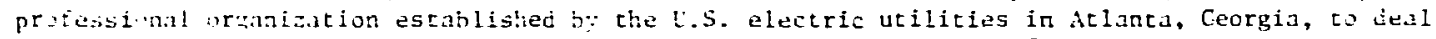

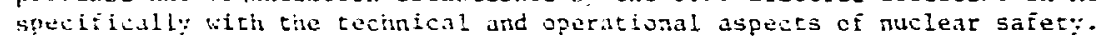

Such of the confusion whil: added to the problens of dealing with the TwI-l accident as it was happening and icsediatel: arcerwards was due to the innilit: of the staf́ to quickly access needed information and data. In its afterach, the several commissions and study sroups made strmag recomendations for remedies. The imclear industry is now making an assesstent of its needs and of the availabilit: of data jases for rapid response to questions about power reactor problums. in ef fort is being made to generate new data jases to fill voids la the available fniormation base and also to irprove data base min.agenent schemes for dyamic, rapid access to the data.

This paper reviews several planned ano existing data bases established for both dynamic on-line access and mure considered response to nuclear pozer reactor probleas. The relationship of the data bases to specif́ic problem areas of resecor licensing and regulation is not always clear hist sote are accessible as a national technolvg: resource in the United 5tates. Embedded in enginc-ing pirsics research and development programs and managed by knowledgeable scientists and engineers, these data bases are an iategral part of the related national programs. At least two of the data bases serve an internacional scientific comunity.

\section{DAT: BASES AND YETHODS DEVELORYE:T}

Engineers on duty during and after the TMI-2 accident expressed their data needs in simple terms. sucin as low ener: buildup factors for noble gas, steel, water, lead. etc. current estimates of power histor: of the reactor core. and generic data iomally available in handbooks, etc. Dynamic on-line access to computers with codes and associated daca libraries would have been a tremendons asset in perforning analyses at the scene of the accident (Hopkins, 1980). The b.S. Nuclenr Regulacary commission (ARC) and the nuclear power industry are studyin both needs. New generic data bases and improvemencs to existing ones, as well as simplified methodology for use on-site are expected to result from these studies.

\footnotetext{
*Research sponsored by the U.S. Department of Energy, under agreement (BA No. AT 1540430 and AF 1510200 , and FTP/A No. 00039 and OHO15) with Oak Ridge National Laboratory, operated by Union Carbide Corporation under cortrict W-7405-eng-26 for the U.S. Department of Energy.
}

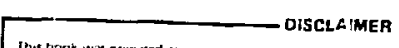

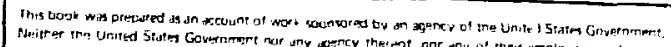

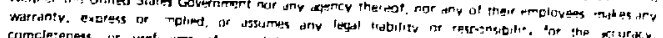

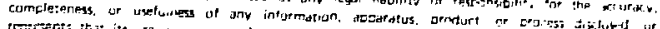

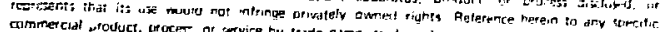

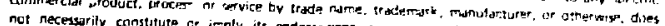

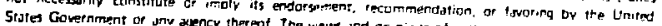

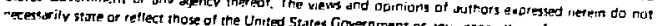

By acceptance of this article. the publisher or recipient acknowledges the U.S. Government's right to retain a nonexclusive, royalty-free license in and to any copyright covering the article. 
NII-2 has reemphasized the importance of reactor operators and the role they pluy in determi:ning the level of safety associated ith nuclear power. In addition to research in improu ing training progrins, much thought is given to human factors and a body of associated information is being collected and ana; zed.

A few specific data bases and associated tanagement s:stems can be iitid, e.g.. SEE-IN, CREDO. and SACRD.

$\underline{\text { SEE-I:H }}$

One of the lessons taught by TM-2 was that there had been visible prior warning of the pussibility of such an accident in the form of less serious events at other plants and at TMI-?. Yet these warnings were not perceived for what they were by wther SRC or the industry. Analyses that were done on the precursor events were not disseminated to the utilities until aiter the accident.

To remedy this situation, NSAC set up a aechanism fur systematically searching plant operating experience for such early warning signs. and a new dala hase system. SEE-IN (Zebioski, 1980), came into being. A large, rapidly searchable data base of licensing information trat is continually updated is an integral part ó the SEE-IN system. Included is a body of data based on the examination of all Licensee Event Reports (LERs) f:om all U.S. nuclear utilities. The establishment and m.- tenance of the data bank is a cuoperative effort of NSAC and INPO with tle assistance of the Nuclear Safety Informatior Center (NSIC) (Cottrel1, 1971, 1977) at the Dak hidge Nittional Laborator; (ORNL) and other contractors. The NSIC LER data base contains 22,000 events vith computerized descriptions which are retrievable ising kewords. An timportant element of SEE-IN is the computer information netsork and conferencing system (XOTEPAi) which permits rapid, comprehensive, userselertive transfer of urgently needed information to all interested parties.

CQREDO

Safety studies :1sually involve an assessment of risk and the cost and benefit of reducing risk. Risk assessment is probabilistic in nature; one estimates the probability that an accident will occur and the damage that will resuit irom it. The product, probability times damage, is the risk, in engineering terms. Essential to risk assessment is the availability of a large body of related data. Several effo'ts are underway tu supply the needed da $t a$.

The Centralized Reifability Data Organization (CREDO) (Kiee, 1980) is a DOE-sponsored program at the nak Ridge National Laboratory (ORNL) as a part of the National Advanced Reactor Reliability Data System. It disseminates advanced reactor reliabllity/availability data and provides limited specialized analysis services for requesting users. Interface and cooperative data exchange with other US and internatic nal data banks is an integral part of the program plan.

A working system for data collection, managenent and distribution is in operation and expected to move from a development stage to routine operation in the next two years. The organization includes a nationally recognized steering committee of experts, and working groups on l) input data, formats and procedures, 2) data evaluation, and 3) output data, formats and procedures, and the oRNL principals and support staf́̆.

Three types of data are collected:

(1) Engineering Datz which contain a complete engineering description of a component and uriquely identify it so that its specific operating and failure history can be tracked. In general, engineering data on a component is collected once, preferably before inftial operation.

(2) Operating Data, i.e., operating hours and/or number of cycles of a component. In CREDO, an estimate of operating hours (or cycles) for a component is obtained by reporting (quarterly) the operating hours for the unit, and then multiplying that by "operating factors" or "Juty factors" which are specified on the component enpineering form. Therefore, the CREDO operating file contains fnformation on unit operating hours.

(3) Event Data is a complete description of an occurrence (faflure), its cause and effects, corrective action taken and time required for various elements of total repair time. Event data are reported as soon after the event as possible.

Al1 of the data management functions - cataloging, storage, searching, retrleval, routine statistical analysis, and routine output - are under control of a versatile data base management system (DBMS) which has been constructed primarily from systems existing at ORNL. The DBMS uses techniques developed for the Oak Ridge Computertzed Herarchial Information System (ORCHIS) (Brooks, 1974) combined with the data management facilities of JaSHUA, a modular system developed (Honeck, 1975) at the Savannah River Laboratory. Additional software has been developed for tasks specific to CREDO needs, e.g. failure-rate estimation. The JOSHLA-ORCHIS combination provides a flexible and efficient data managenent system to perform the varied tasks of a rellabilfty data center. 

The Akc/asR batal bank system is designed to manage data pertinent to research investigating the loss of coolant aceident iu: both pressurized water reactors and bolling water reactors. The data is in the form of raw neasured data that has not been processed with the exception of conversion to engineering units and application of callbration factors. Data sources finclude experimental frograns sponsured by NRC, other government agencies, private industry, and foreign governments.

The IDMC gtves assistance as requited to SRC's many data managemeat problems. It includes a dynanic treatment of safety-related computing technology and data bases, the enhancement and standardization of computing technology for use in licensing and regulating nuilear power plants, and the building of safety-related data bases for dynamic on-1ine access and for rapid response as needed. $A s$ an afterath of the TMI-2 accident. TDMC state nembers became involved in a survey of NRC data needs and making recommendations for the establishment of new, improved, easily accessed data bases. At the same time, efforts are undenvay to generate data which was not avallable when needed by engineers at the TMI-2 site.

NSIC

The oRNL Nuclear Safety Informaticn Center (NSIC) (Cotcre1!, 1971, 1977) is a national center for collecting, storing, evaluating, and disseminating nuclear-safety information generated throughout the world. Established in 1963, NSIC is sponsored by DOE and NRC to analyze current information, produce state-of-the-art repcrts, and anster technical iaquiries. The scope encompasses all types of nuclear facilities and reactors from water-cooled to liquid-metal fast breeders, along with associated considerations such as siting and eperating experience. Its products include the binonthly cechnical progress review, Nuclear Safety, which is sold on a subscription basis by the U.S. Government printing office, Weshington, D.C.

$A$ quick measure of the impact of T:II-2 on NSIC is the change in the Center's overall budget over the past year - an increase of about $80 \%$, primarily in studies and evaluations. Immediate impacts were (1) support of the industry advisory group at the TML site. (2) assistance to EPRI in the formztion of NSAC Safety Analysis Center (NSAC), (3) preparation of a report on reactor accidents for the kemeny Cormission, and (4) a greatly expanded use of NSIC resources.

The Center has seen the use of its data base of Licensee Event Reports (LERs) expanded dramatically, both in the response to technical inquiries and as one of the most important resources used in performing special studies. As an cxample, the Accldent Sequence Precursor Study has screened 22,000 LERs and selected sbout $0.7 \%$ as potential precursors to severe core damage accidents. Event "trees" are being corstructed for the selected events, and the accidents are being analyzed for lessons to be learned.

NSIC and fts sponsors plan new and expanded data bases with dynatic on-line access a standard feature.

\section{CONCLUSION}

The urgency of the TMI-2 incident demanded prompt answers to an imperious situation. In responding to these challenging circumstinces, joth government and industry recognized deficiencies in both availability of essential retrievable data and calculational capabilittes designed to respond immediately to actual abnormal events. Each responded by inftiating new programs to provide a remedy for tine deficiencies and to generally imprave all safety measures tn the nuclear power industry,

Many data bases and information centers of fer generic data and other technoloay resources which are generally useful in support of nuclear safety programs. A $f \in k$ centers can offer rapid access to calculational methods and associated data and more will make an effort to do so.

As a beneficial spin-off from the lessons learned frra MII-2, more technical effort and financial resources will be devoted to the prevention of accidents, ani to improvement of safety measures in the immediate future and for long term $R$ \& $D$ programs by both government and the nuclear power industry.

\section{REFERENCES}

Andrews II, J. B., C. L. Whitmarsh, J. J. Woors, and D. A. Nttti (1980). Reactor physics and shieldíng implications of TMI-2. To be published in Proceedings of ANS Topical Conference on 1980 advances in reactor physics anó shielding, iun Valley, Idaho, September 14-17. 1980.

Brooks, A. A. (1974). Dak Ridge computerized hferarchial infurmation system (ORCHIS) status report July, 1973. Oak Ridge National Laboratory, Oak Ridge, Tennessee. ORNL-4929.

Cottrell, W. B., and J. R. Buchanan (1971). NSIC computerized information techniques. Oak Ridge Natiunal Laboratory, Oak Ridge, Tennessee. ORNL-NSIC-y2.

Cottrall, W. B. (1977). Resources available at the :uclear Safety Information Center. Am. Nuc. Soc. Irans., 26, 567-568.

Forsberg, V. M., J. W. Arwood, N. M. Greene, and G. B. Raiford (1980). SACRD - a data base for fast reactor safety computer codes - operational procedures. Oak Ridge Nitional Laboratory, Computer Sciences Division, Oak Ridge, Tennessee. ORNL/CSD-53. 


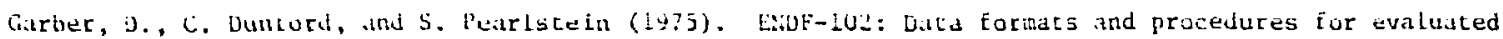
nuclear data [ile, ENDF. Rrookhaven hational laboratory, NIIS, Lipton, Niew York. ERDA Report BNL-NCS-50496.

Greene, N. W. G. F. Flanagan, and H. Alter (1977). Central computerized data base for LFBR safety codes. In B. Breytus (Ed.), Proceedings of the 5th Biennial International CoDATA Corference, June 28 July 1, 1976, Boulder, Colorado, Pergamon Press. New York. Pp. 389-391.

Honeck, H. C. (1975). The Joshlis system. Savannah River Laboratory, NTIS, Aiken, South Carolina. ERDA Report DP-1380.

Hopkins, H. (1980). Informal communtcation with Bechtel Corporation, Bechesda, Staryland.

Knee, H. E., T. F. Bott, G. W. Cunningham, N. M. Greene, P. M. Haas, S. D. Hudson, and J. J. Manning (1980). Development of tise centralized reliabillty data organization (CREDO). To be published in Froceedings of 3rd European Reliability Data Bank Seminar, Bradford, United Kingdom, April 9-11, 1980 .

Maskewicz, B. F., R. W. Roussin, and D. K. Trubey (1972). The Radiacion Shielding Information Center - a unifying force in the international shielding community. Proceedings of 4 th International Conference on Reactor Shielding, Vol. 1, The French Atomic Energy Commission, Parts, France. Pp. 215-225.

Roussin, R. W., B. F. Maskewitz, and D. K. Trubey (1975). Radiation Shielding Information Center data activities. Nuclear Cross Sections and Technology, Proceedings of a Conference, NBS Special Publication 425, Vol. I, U.S. Government Printing office, Washington, D.C. Pp. 363366 .

Trubey, D. K., B. F. Maskewitz, and R. W. Roussin (1977). Computer codes and data available from the Radiation Shielding Information Center. Radiation Phvsics, Proceedings of the International Symposium on Radiation Phvsics, Calcutta, India, 1974, NBS Special Publication 461, U.S. Government Printing of ice, Washington, D. C. pp. 171-173.

Zebrosti, E. L., and Y. C. Leverett (1980). The Nuclear Safety Analysis Center. To be published in Proceedings of ANS Topical Conference on 1980 advances in reactor physics and shielding, Sun Valley, Tdiho, September 14-17, 1980. 